\title{
Inhaltsverzeichnis / Contents
}

Iris Brahms

10 Vorwort und Dank / Preface

Gezeichnete Evidentia. Zur Einführung / Drawn Evidentia. Introduction Iris Brahms

20 Gezeichnete Evidentia. Zur Einführung / Drawn Evidentia. Introduction

(Inter-)Medialität bei Lorenzo Monaco / (Inter)mediality in the Cuvre of Lorenzo Monaco

Philippa Sissis

59 Von Licht und Stein?

Ein Versuch zu den Berliner Blättern Lorenzo Monacos

Iris Helffenstein

79 Intermediale Verfahren im studietto

Zu Materialästhetik und Medialität von Verre églomisé und Goldgrund im italienischen Spätmittelalter bis Lorenzo Monaco

\section{Zur Auslotung der Farbigkeit / Exploring Colourfulness}

Claudia Reufer

103 auf giftig-grünem Kreidegrund

Zeichnungen auf farbigem Grund im sog. Gozzoli-Album

Iris Brahms

125 Weiß auf Schwarz

Die Umkehrung der Evidenzerzeugung und ihre optischen wie ästhetischen Folgen 
Assimilation an die Malerei: Die Suche nach dem Mittelton /

Assimilating Painting: The Search for the Midtone

Elvira Bojilova

153 Farbgrund und Glanzpunkt

Techniken und Ästhetiken des Reflexionslichts in der Kunstliteratur um 1600

Joost Keizer

173 Free Ground

The Structure of Drawing in the Dutch Republic

Blaue und nicht-weiße Papiere: Zwischen Stilmerkmal und Ökonomie /

Blue and non-white Papers: Stylistic and Economic Choices

Alexa McCarthy

197 Govert Flinck's Figure Studies on Blue Paper

The Role of Materials in Stylistic Development

Armin Häberle

217 Zeichnen auf nicht-weißen Papieren

Ökonomische und bildkünstlerische Reflexionen bei Vouet, Poussin, Dughet und van Dyck

\section{Kunsttechnologische Untersuchungen / Art-technological Investigations}

Michael Venator

243 Recycling durch Grundierung

Zu einem Blatt von Caspar Fraisinger

Erzsébet Mózer

253 Drawing Techniques on Coloured Ground Paper

Case Studies from the Museum of Fine Arts, Budapest - Collection of Prints and Drawings

\section{Epilog / Epilogue}

Anne Eusterschulte

272 Au fond - am Farbgrund der Zeichnungen. Epilog /

Au fond - on the Colour Ground of the Drawings. Epilogue

318 Bildnachweise / Image Credits 

L'image est l'évidence de l'invisible. *

* Jean-Luc Nancy, Au fond des images, Paris 2003, S. 30. 